\title{
PEDOFUNCTIONS APPLIED TO THE LEAST LIMITING WATER RANGE TO ESTIMATE SOIL WATER CONTENT AT SPECIFIC POTENTIALS
}

\author{
Renan F. R. Tavanti ${ }^{1 *}$, Onã da S. Freddi², Tauan R. Tavanti ${ }^{3}$, Adriel Rigotti ${ }^{2}$, \\ Wellington de A. Magalhães ${ }^{4}$
}

\author{
${ }^{1 *}$ Corresponding author. Universidade Estadual Paulista "Júlio de Mesquita Filho" - UNESP/ Ilha Solteira - SP, Brasil. \\ E-mail: renan.tavanti91@gmail.com | ORCID ID: https://orcid.org/0000-0002-4496-9660
}

\section{KEYWORDS}

Soil physics, soil physical quality indicator, available water, pedotransfer functions, artificial neural networks.

\begin{abstract}
The least limiting water range (LLWR) is a soil physical quality indicator that receives much attention. It has been criticized and put to the test regarding mathematical models that compose it since they describe the behavior of soil physical attributes in a simplified way. This study aimed to assess the efficiency of some pedofunctions proposed in the literature and artificial neural networks on the accuracy in predicting soil water retention at potentials equivalent to field capacity $(\theta \mathrm{FC})$ and permanent wilting point $(\theta \mathrm{PWP})$. In other words, to apply the best models to LLWR of two soil types (Oxisol and Ultisol) and verify changes in their structure. The results indicated that pedofunctions using sand, silt, clay, bulk density, and soil organic matter contents are more efficient in estimating $\theta \mathrm{FC}$ and $\theta \mathrm{PWP}$. However, the use of multiple linear regression models to predict $\theta \mathrm{FC}$ values below $0.20 \mathrm{~m}^{3} \mathrm{~m}^{-3}$ may present a slight tendency to overestimate it, which is not observed in the neural networks. As in $\mathrm{R}^{2}$, equations from neural networks were more efficient in estimating $\theta F C$ and $\theta \mathrm{PWP}$. Pedofunctions used to calculate LLWR differ in the establishment of the critical soil bulk density, exposing the limitations of the model.
\end{abstract}

\section{INTRODUCTION}

Soil physical quality cannot be measured directly, but it is assessed through attributes such as porosity, bulk density, penetration resistance, and water content available to plants (Guimarães et al., 2013). Soil physical quality was better investigated by Letey (1985), who proposed the concept of 'non-limiting water range', which integrates the relationships between soil attributes and water content available to plants. Silva et al. (1994) improved this concept when assembling mathematical models for estimating soil moisture in the field capacity, permanent wilting point, airfilled porosity, and soil penetration resistance, originating a soil structural quality indicator known as least limiting water range. Tormena et al. (1998) later introduced this indicator in Brazil as Intervalo Hídrico Ótimo.

The least limiting water range (LLWR) has been received much attention in Brazil and applied in several studies. Among them, Freddi et al. (2009) assessed compaction levels of an Oxisol and its physical quality reduction processes, as well as yield reduction of two maize hybrids as a response to compaction. The authors verified that, at certain levels of soil bulk density, water content should be above the field capacity to avoid limitations due to soil penetration resistance and meet the water requirements of hybrids. In this case, the intense machinery traffic led to soil structural degradation. In addition, the authors proposed soil decompaction actions when bulk density reached $1.46 \mathrm{Mg} \mathrm{m}^{-3}$, considered as critical in LLWR. Betioli Junior et al. (2012) analyzed an Oxisol after 30 years of no-tillage and observed a decrease in LLWR due to an increase in bulk density, regardless of the used critical soil penetration resistance, which was $2 \mathrm{MPa}$.

Despite the studies that consolidate LLWR as a soil physical quality indicator, it has been criticized and its validity put to the test by several authors (Gubiani et al., 2013, Jong Van Lier \& Gubiani, 2015; Cecagno et al., 2016). These studies have questioned the efficiency of the linear mathematical model used to determine LLWR since the relationships between soil attributes are not linear and describe them in a relatively simple way is still one of the challenges of soil physics (Klein et al., 2016; Jong Van Lier \& Gubiani, 2015).

\footnotetext{
${ }^{2}$ Universidade Federal de Mato Grosso - UFMT/ Sinop - MT, Brasil.

${ }^{3}$ Universidade Estadual Paulista "Júlio de Mesquita Filho" - UNESP/ Ilha Solteira - SP, Brasil.

${ }^{4}$ Universidade Federal de Mato Grosso - UFMT/ Cuiabá - MT, Brasil.

Received in: 1-19-2018

Accepted in: 5-29-2019
} 
Over the years, researchers have been proposing mathematical models to estimate soil water retention using attributes that correlate directly with one another, such as clay, silt, sand, soil organic matter content, and bulk density (Barros et al., 2013; Medrado \& Lima, 2014; Medeiros et al., 2014). These models are also known as pedofunctions or pedotransfer functions (PTF) and can be applied to LLWR.

Most models currently available were developed for temperate regions (Gupta \& Larson, 1979; Rawls et al., 1982; Saxton et al., 1986), where edaphoclimatic properties and soil mineralogical characteristics are different from tropical regions. For Brazil, some models have already been established (Reichert et al., 2009, Barros et al., 2013, Medeiros et al., 2014), but their validity in soils submitted to agricultural management different from those of the original database may make them unsuitable for use.

In the case of complex systems, mathematical modeling techniques may be more efficient in predicting soil water content, such as artificial neural networks (ANN) (Jana et al., 2012; Jana \& Mohanty, 2012; Nguyen et al., 2017). ANNs have shown high performance due to factors such as robust and parallel distributed structure (layers of neurons), generalization and learning efficiency that make them capable of solving complex problems (Leal et al., 2015). In addition, they are tolerant to outliers, in which they are normalized in the layers of neurons, allowing the modeling of distinct variables and their non-linear relationships. This computational technique simulates the neural structure of intelligent organisms, which acquire knowledge through the experience and acquisition of punctual information.

As an example of the application of ANNs in agricultural research, Leal et al. (2015) reported their efficiency to estimate maize grain yield through soil attributes such as particle size distribution, soil organic matter content, cation exchange capacity, and base saturation. Ebrahimi et al. (2019) compared the efficiency of mathematical models in the estimates of the biological parameters of soil microbiota from their attributes and verified that ANN was more efficient than multiple linear regressions.

Based on these observations, this study aimed to assess the efficiency of some PTFs proposed in the literature and ANNs on the accuracy in predicting soil water retention at potentials equivalent to field capacity $(\theta \mathrm{FC})$ and permanent wilting point $(\theta \mathrm{PWP})$. In other words, to apply the best models to LLWR of two soil types (Oxisol and Ultisol) and verify changes in their structure.

\section{MATERIAL AND METHODS}

The data were obtained from two representative soils of the Mato Grosso State, Brazil, classified according to the Brazilian Soil Classification System (Embrapa, 2013) as a Dystrophic Red-Yellow Latosol and Dystrophic RedYellow Argisol, located at the geographical coordinates $59^{\circ} 11^{\prime} 59.0^{\prime \prime} \mathrm{W}$ and $12^{\circ} 35^{\prime} 49^{\prime \prime} \mathrm{S}$ and $56^{\circ} 01^{\prime} 16.8^{\prime \prime} \mathrm{W}$ and $9^{\circ} 54^{\prime} 04^{\prime \prime} \mathrm{S}$, with an altitude of 350 and $283 \mathrm{~m}$, respectively.
According to the U.S. Department of Agriculture (Soil Survey Staff, 2014), the soils are classified as Oxisol and Ultisol, respectively. We will use in this study the USDA classification for standardization purposes.

These soils were sampled from October 2015 to August 2016. The Oxisol was under integrated croplivestock systems, with an intense crop rotation consisting of soybean as main crop and maize as the second crop intercropped with forage species of the genus Urochloa. In some situations, millet or sorghum was chosen instead of maize as the second crop. The forage crops subsidized livestock farming during the dry season until the beginning of rains. The mean annual stocking rate was 2 animals of $450 \mathrm{~kg} \mathrm{ha}^{-1}$ year $^{-1}$.

The Ultisol was under Brachiaria brizantha cv. Marandu for more than ten years managed for extensive livestock farming, which was not subjected to any soil tillage. The mean annual stocking rate was 1.5 animals of $450 \mathrm{~kg} \mathrm{ha}^{-1}$ year $^{-1}$.

Soil physical and chemical attributes were determined from 156 undisturbed and 30 disturbed soil samples. Disturbed soil samples were collected at depths of $0-0.10$ and $0.10-0.20 \mathrm{~m}$ with a Dutch auger. Undisturbed soil samples were taken using stainless steel volumetric rings with $5 \mathrm{~cm}$ high $\times 5 \mathrm{~cm}$ in diameter $\left(98.17 \mathrm{~cm}^{3}\right)$ from trenches at depths of $0-0.10$ and $0.10-0.20 \mathrm{~m}$.

Disturbed soil samples were taken to the laboratory, air dried, and sieved in $200 \mathrm{~mm}$ diameter stainless steel mesh sieves. Thus, particle size distribution was determined by the pipette method and organic matter contents $(\mathrm{OM})$ by potassium dichromate oxidation (Embrapa, 2011). Undisturbed soil samples were saturated with water in plastic trays and subjected to tensions of $0,30,60$, and 100 $\mathrm{hPa}$ in a sandbox and $300,600,1000,5000$, and $15000 \mathrm{hPa}$ in pressure chambers with a porous plate. After each potential had reached moisture balance, the samples were weighed in order to find the water content. Subsequently, they were subjected to penetration resistance (PR), determined by a bench electronic penetrometer. The penetrometer had the following characteristics: load cell of $20 \mathrm{~kg}$, penetration pin of $3 \mathrm{~mm}$ with $4 \mathrm{~mm}$ tip in a cone shape with $30^{\circ}$ angle, and tip base area of $7.06 \mathrm{~mm}^{2}$. The constant penetration rate was $10 \mathrm{~mm} \mathrm{~min}^{-1}$, with two replications per sample, totaling 180 readings per replication. Therefore, the PR data taken from the first centimeter at the top and bottom of the rings were discarded. Thus, each microprofile consisted of PR readings recorded along a vertical transect of $3 \mathrm{~cm}$, acquired from 1 to $4 \mathrm{~cm}$ deep, within a core of $5 \mathrm{~cm}$ of soil height, in accordance with the representative elementary volume theory. The PR value of each soil sample was obtained from the overall mean of records.

Subsequently, the undisturbed soil samples were oven-dried at $105^{\circ} \mathrm{C}$ for 24 hours. The total porosity (TP), bulk density (BD), and soil water content at each tension were calculated (Embrapa, 2011). 
For LLWR construction, the model proposed by Busscher (1990) was used to build the PR curve. The water content in which soil penetration resistance is limiting to root growth was obtained by [eq. (1)]:

$$
\theta \mathrm{PR}=\left(\frac{\mathrm{PRc}}{\exp ^{\beta 1} \times\left(\mathrm{BD}^{\beta 2}\right)}\right)^{\frac{1}{\beta 3}}
$$

Where:

$\theta \mathrm{PR}$ is the volumetric soil water content in which PR reaches the critical value $\left(\mathrm{m}^{3} \mathrm{~m}^{-3}\right)$;

$\mathrm{BD}$ is the soil bulk density $\left(\mathrm{Mg} \mathrm{m}^{-3}\right)$;

PRc is the critical PR value, and

$\beta 1, \beta 2$, and $\beta 3$ are the adjustment parameters of the equation. The PRc value of $2 \mathrm{MPa}$ proposed by Taylor et al. (1966) was used.

The water content in which aeration porosity is $10 \%$, i.e., air-filled capacity ( $\theta \mathrm{AFC})$, was found through [eq. (2)]:

$$
\theta \mathrm{AFC}=\mathrm{TP}-0.1
$$

Where:

$$
\text { TP is the total porosity }\left(\mathrm{m}^{3} \mathrm{~m}^{-3}\right) \text {. }
$$

For the other LLWR curves corresponding to $\theta \mathrm{FC}$ and $\theta \mathrm{PWP}$, the pedofunctions proposed by several authors were used, as shown in Tables 1 and 2, respectively.
The multilayer perceptron ANN was also tested. For this, $75 \%$ of the data were used for ANN training and $25 \%$ for validation. The supervised learning was used with two sets of values, i.e., input and output values. Training consisted of a parameter optimization problem (synaptic weights) to respond to the inputs as expected until the error between observed and estimated values generated by ANNs reached the desired minimum value, i.e., close to zero (Leal et al., 2015).

The ANNs consisted of entries (inputs) corresponding to the soil attributes sand (SD), silt (SIL), clay $(\mathrm{CL}), \mathrm{BD}$, and OM. Outputs (response variables) were the respective soil water contents equivalent to $\theta \mathrm{FC}$ and $\theta$ PWP. We chose the composition of two hidden layers, one with seven neurons and other with five neurons, respectively. Thus, the ANN architecture could be described as 5-7-5-2 (Figure 1). The activation function used was the hyperbolic tangent, as described in [eq. (3)]:

$$
\operatorname{Tan} H=\frac{\sinh (x)}{\cosh (x)}
$$

Where:
TanH is the hyperbolic tangent;

\begin{tabular}{|c|c|c|c|}
\hline Source & Soil & Model $^{1}$ & $\mathrm{R}^{2}$ \\
\hline & \multicolumn{3}{|c|}{ Oxisol } \\
\hline Silva et al. (1994) & CAN & $\theta \mathrm{FC}=\exp ^{-0.873^{*}} \mathrm{BD}^{0.511^{*}} 100^{-0.115}$ & $0.96 *$ \\
\hline Gupta \& Larson (1979) & USA & $\theta \mathrm{FC}=0.001^{*} \mathrm{SD}+0^{n s} \mathrm{ST}+0^{n s} \mathrm{CL}+0^{n s} \mathrm{OM}+0.179 * \mathrm{BD}$ & $0.99 *$ \\
\hline Rawls et al. (1982) & USA & $\theta \mathrm{FC}=-0.588^{*}+0^{n s} \mathrm{SD}+0^{n s} \mathrm{ST}+0.027^{*} \mathrm{CL}+0^{n s} \mathrm{OM}+0^{n s} \mathrm{BD}$ & $0.74 *$ \\
\hline Saxton et al. (1986) & USA & $\theta \mathrm{FC}=\exp \left[\left(-1.335^{*}-\ln \mathrm{A}\right) / \mathrm{B}\right]$ & $0.57 *$ \\
\hline Ritchie et al. (1999) & USA & $\mathrm{GM}=0.169^{*}(\mathrm{CL} / \mathrm{SD})^{0.405^{*}} \rightarrow \theta \mathrm{FC}=\mathrm{GM} \times \mathrm{BD}$ & $0.47^{*}$ \\
\hline Arruda et al. (1987) & BRA & $\theta \mathrm{FC}=0.040^{*}+0^{n s}(\mathrm{CL}+\mathrm{ST})+1.22 \times 10^{-4^{*}}(\mathrm{CL}+\mathrm{ST})^{2}$ & $0.74 *$ \\
\hline van den Berg et al. (1987) & TRP & $\theta \mathrm{FC}=-1.752^{*}+0.053^{*} \mathrm{CL}+0^{n s} \mathrm{ST}+0.132^{*} \mathrm{OM}$ & $0.74^{*}$ \\
\hline \multirow[t]{2}{*}{ Oliveira et al. (2002) } & BRA & $\theta \mathrm{FC}=0.015^{*} \mathrm{ST}+0.003^{*} \mathrm{CL}$ & $0.99 *$ \\
\hline & \multicolumn{3}{|c|}{ Ultisol } \\
\hline Silva et al. (1994) & CAN & $\theta \mathrm{FC}=\exp ^{-0.95 I^{*}} \mathrm{BD}^{-0.163^{*}} 100^{-0.124^{*}}$ & $0.34 *$ \\
\hline Gupta \& Larson (1979) & USA & $\theta \mathrm{FC}=0^{n s} \mathrm{SD}+0^{n s} \mathrm{ST}+0^{n s} \mathrm{CL}+0.017^{*} \mathrm{OM}+0.109^{*} \mathrm{BD}$ & $0.99 *$ \\
\hline Rawls et al. (1982) & USA & $\theta \mathrm{FC}=0.382-0.003^{*} \mathrm{SD}+0^{n s} \mathrm{ST}+0^{n s} \mathrm{CL}+0^{n s} \mathrm{OM}+0^{n s} \mathrm{BD}$ & $0.72 *$ \\
\hline Saxton et al. (1986) & USA & $\theta \mathrm{FC}=\exp \left[\left(-0.665^{*}-\ln \mathrm{A}\right) / \mathrm{B}\right]$ & $0.60^{*}$ \\
\hline Ritchie et al. (1999) & USA & $\mathrm{GM}=0.255^{*}(\mathrm{CL} / \mathrm{SD})^{0.167^{*}} \rightarrow \theta \mathrm{FC}=\mathrm{GM} \times \mathrm{BD}$ & $0.01 *$ \\
\hline Arruda et al. (1987) & BRA & $\theta \mathrm{FC}=0.107^{*}+0.003^{*}(\mathrm{CL}+\mathrm{ST})+0^{n s}(\mathrm{CL}+\mathrm{ST})^{2}$ & $0.72 *$ \\
\hline van den Berg et al. (1987) & TRP & $\theta \mathrm{FC}=0^{n s}+0^{n s} \mathrm{CL}+0^{n s} \mathrm{ST}+0^{n s} \mathrm{OM}$ & - \\
\hline Oliveira et al. (2002) & BRA & $\theta \mathrm{FC}=0.004^{*} \mathrm{ST}+0.006^{*} \mathrm{CL}$ & $0.97 *$ \\
\hline
\end{tabular}
sinh is hyperbolic sine,
cosh is hyperbolic cosine.

TABLE 1. Source of pedotransfer functions used to estimate soil water content in the field capacity ( $\theta$ FC).

${ }^{1}$ CAN: Canadian soils, BRA: Brazilian soils, USA: American soils, TRP: Tropical soils; CL: clay (dag kg $\left.{ }^{-1}\right)$, ST: silt (dag kg-1), SD: sand (dag $\left.\mathrm{kg}^{-1}\right)$, BD: bulk density $\left(\mathrm{g} \mathrm{cm}^{-3}\right), \mathrm{OM}$ : organic matter $\left(\right.$ dag kg$\left.{ }^{-1}\right)$, GM: gravimetric moisture at -100 or $-15000 \mathrm{hPa}\left(\mathrm{kg} \mathrm{kg}^{-1}\right) ; \mathrm{A}=\exp [-4.396$ $\left.-0.0715 \mathrm{CL}-4.88 \times 10^{-4}\left(\mathrm{SD}^{2}\right)-4.28 \times 10^{-5}\left(\mathrm{SD}^{2}\right) \mathrm{CL}\right] ; \mathrm{B}=-3.14-0.002\left(\mathrm{CL}^{2}\right)-3.48 \times 10^{-5}\left(\mathrm{SD}^{2}\right) \mathrm{CL}$. 
TABLE 2. Source of pedotransfer functions used to estimate soil water content in the permanent wilting point ( $\theta$ PWP).

\begin{tabular}{|c|c|c|c|}
\hline Source & Soil & Model $^{1}$ & $\mathrm{R}^{2}$ \\
\hline & \multicolumn{3}{|c|}{ Oxisol } \\
\hline Silva et al. (1994) & CAN & $\theta \mathrm{PWP}=\exp ^{-0.873^{*}} \mathrm{BD}^{0.511^{*}} 15000^{-0.115}$ & $0.96^{*}$ \\
\hline Gupta \& Larson (1979) & USA & $\theta \mathrm{PWP}=0^{n s} \mathrm{SD}-0.017^{*} \mathrm{ST}+0.010^{*} \mathrm{CL}+0^{n s} \mathrm{OM}+0^{n s} \mathrm{BD}$ & $0.99 *$ \\
\hline Rawls et al. (1982) & USA & $\theta \mathrm{PWP}=1.034^{*}+0^{n s} \mathrm{SD}-0.099^{*} \mathrm{ST}+0^{n s} \mathrm{CL}+0^{n s} \mathrm{OM}+0^{n s} \mathrm{BD}$ & $0.95^{*}$ \\
\hline Ritchie et al. (1999) & USA & $\theta \mathrm{PWP}=\theta_{\mathrm{pwp}^{*}}-1.35 \times 10^{-10^{*}} \exp ^{\left(0.285^{*} \mathrm{SD}\right)}$ & $0.90^{*}$ \\
\hline Arruda et al. (1987) & BRA & $\theta \mathrm{PWP}=-0.382^{*}+0.013^{*}(\mathrm{CL}+\mathrm{ST})$ & $0.94 *$ \\
\hline van den Berg et al. (1987) & TRP & $\theta \mathrm{PWP}=1.034^{*}+0^{n s} \mathrm{CL}-0.099^{*} \mathrm{ST}$ & $0.95 *$ \\
\hline \multirow[t]{2}{*}{ Oliveira et al. (2002) } & $\mathrm{BRA}$ & $\theta \mathrm{PWP}=0^{n s} \mathrm{SD}-0.017^{*} \mathrm{ST}+0.010^{*} \mathrm{CL}+0^{n s} \mathrm{BD}$ & $0.99 *$ \\
\hline & \multicolumn{3}{|c|}{ Ultisol } \\
\hline Silva et al. (1994) & CAN & $\theta \mathrm{PWP}=\exp ^{-0.951^{*}} \mathrm{BD}^{-0.163^{*}} 15000^{-0.124^{*}}$ & $0.34^{*}$ \\
\hline Gupta \& Larson (1979) & USA & $\theta \mathrm{PWP}=0^{n s} \mathrm{SD}+0^{n s} \mathrm{ST}+0.003^{*} \mathrm{CL}+0.019^{*} \mathrm{OM}+0.020^{*} \mathrm{BD}$ & $0.99 *$ \\
\hline Rawls et al. (1982) & USA & $\theta \mathrm{PWP}=0.293^{*}-0.002^{*} \mathrm{SD}+0^{n s} \mathrm{ST}+0^{n s} \mathrm{CL}+0^{n s} \mathrm{OM}+0^{n s} \mathrm{BD}$ & $0.70^{*}$ \\
\hline Ritchie et al. (1999) & USA & $\theta \mathrm{PWP}=\theta_{\mathrm{pwp}}{ }^{*}-2.51 \times 10^{-5^{*}} \exp ^{\left(0.087^{*} \mathrm{SD}\right)}$ & $0.78^{*}$ \\
\hline Arruda et al. (1987) & BRA & $\theta \mathrm{PWP}=0.088^{*}+0.002^{*}(\mathrm{CL}+\mathrm{ST})$ & $0.70 *$ \\
\hline van den Berg et al. (1987) & TRP & $\theta \mathrm{PWP}=0.088^{*}+0.002^{*} \mathrm{CL}+0.002^{*} \mathrm{ST}$ & $0.70^{*}$ \\
\hline Oliveira et al. (2002) & BRA & $\theta \mathrm{PWP}=0^{n s} \mathrm{SD}+0.003^{*} \mathrm{ST}+0.005^{*} \mathrm{CL}+0^{n s} \mathrm{BD}$ & $0.97^{*}$ \\
\hline
\end{tabular}

${ }^{1}$ CAN: Canadian soils, BRA: Brazilian soils, USA: American soils, TRP: Tropical soils; CL: clay (dag kg-1 $)$, ST: silt (dag kg-1), SD: sand (dag $\left.\mathrm{kg}^{-1}\right)$, BD: bulk density $\left(\mathrm{g} \mathrm{cm}^{-3}\right)$, OM: organic matter $\left(\mathrm{dag} \mathrm{kg}^{-1}\right)$, GM: gravimetric moisture at -100 or $-15000 \mathrm{hPa}\left(\mathrm{kg} \mathrm{kg}^{-1}\right), \theta_{\text {pwp }} *$ : mean water content at the permanent wilting point $\left(\mathrm{m}^{3} \mathrm{~m}^{-3}\right)$.

(A)

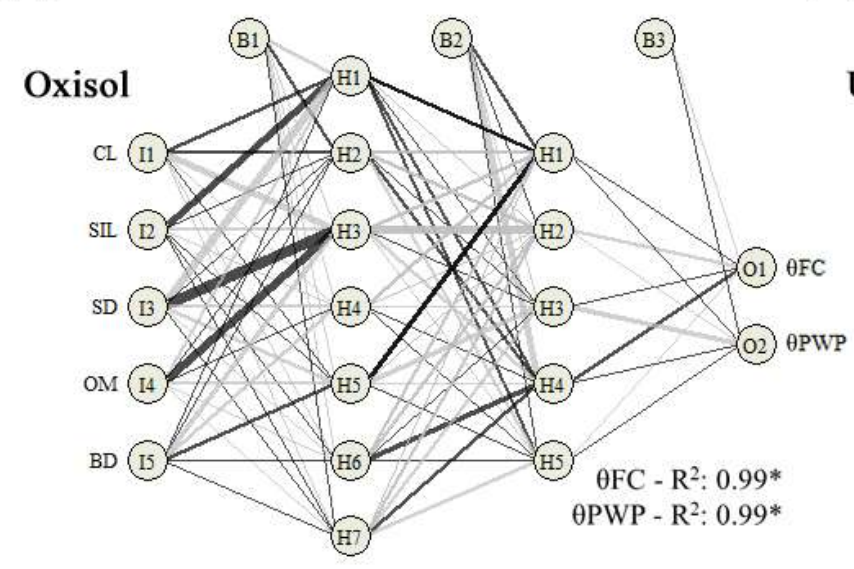

(B)

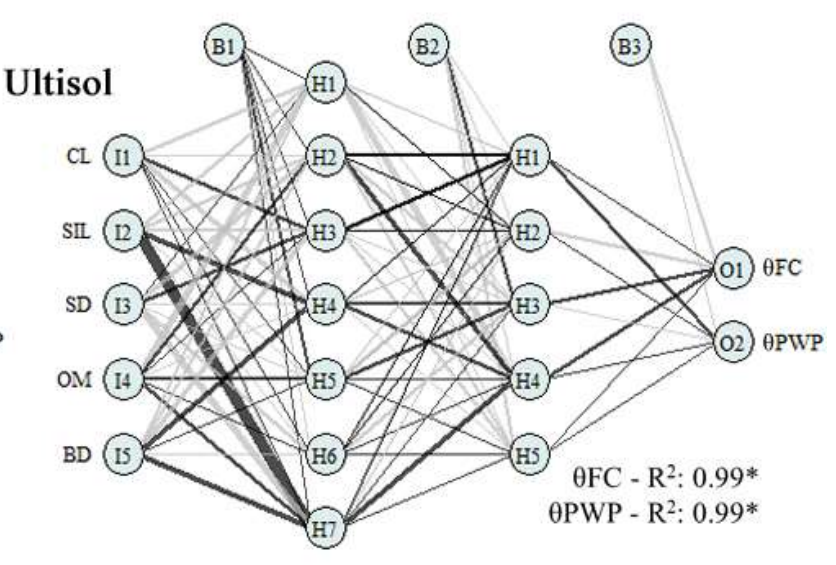

Synaptic weighting $>0$

Synaptic weighting $<0$

FIGURE 1. Artificial neural network architecture (5-7-5-2) used to estimate $\theta$ FC and $\theta$ PWP in an Oxisol (A) and Ultisol (B). Circles with letter B indicate the biases assigned to each layer of neurons, and $\mathrm{I}, \mathrm{H}$, and $\mathrm{O}$ indicate input attributes, neurons, and outputs of $\theta \mathrm{FC}$ and $\theta \mathrm{PWP}$, respectively.

The data were submitted to the Shapiro \& Wilk normality test ( $\mathrm{p}>0.05$ ) using the software R (R Development Core Team, 2015). Outliers with values 2.5 times higher than the interquartile range were removed, respecting the limit of $10 \%$ of the total observations of each treatment (soil type). Subsequently, a descriptive analysis was performed by calculating the mean, median, minimum, and maximum, standard deviation, coefficient of variation (CV), skewness, and kurtosis. The proposed pedofunctions were adjusted for the respective data sets. The neuralnet package was accessed for ANN training following the previously described criteria for assembly of its structure, using the "plotnet" function for network plotting.

The highest coefficient of determination $\left(\mathrm{R}^{2}\right)$ and lowest mean square error (MSE), root mean square error (RMSE), and mean absolute percentage error (MAPE) were used in order to compare the efficiency of pedofunctions in predicting values.

$$
\mathrm{MSE}=\frac{1}{\mathrm{n}} \sum_{\mathrm{i}=1}^{\mathrm{n}}\left(\mathrm{e}_{\mathrm{i}}-\mathrm{m}_{\mathrm{i}}\right)^{2}
$$




$$
\begin{aligned}
& \mathrm{RMSE}=\sqrt{\frac{1}{\mathrm{n}} \sum_{\mathrm{i}=1}^{\mathrm{n}}\left(\mathrm{e}_{\mathrm{i}}-\mathrm{m}_{\mathrm{i}}\right)^{2}} \\
& \mathrm{MAPE}=\frac{\sum_{\mathrm{i}=1}^{\mathrm{n}}\left(\mathrm{e}_{\mathrm{i}}-\mathrm{m}_{\mathrm{i}}\right)}{\sum_{\mathrm{i}=1}^{\mathrm{n}} \mathrm{m}_{\mathrm{i}}} \times 100
\end{aligned}
$$

Where:

$\mathrm{n}$ is the number of sampling points;

$\mathrm{e}_{\mathrm{i}}$ is the value estimated by the pedofunctions, and

$\mathrm{m}_{\mathrm{i}}$ is the measured value (observed).

\section{RESULTS AND DISCUSSION}

Both soils showed a high BD, with mean values of 1.356 and $1.505 \mathrm{Mg} \mathrm{m}^{-3}$ for the Oxisol and Ultisol, respectively (Table 3). Variations of minimum and maximum values of 0.920 and $1.545 \mathrm{Mg} \mathrm{m}^{-3}$ for the Oxisol and 1.180 and $1.760 \mathrm{Mg} \mathrm{m}^{-3}$ for the Ultisol indicated the existence of potentially compacted sites and sites with a structure not affected by management systems. Based on DB for the construction of pedofunctions, this variability is desirable, as they perform estimates with a wide range of values under previously non-sampled conditions. According to Gomes (2000), the variability of the assessed attributes can be classified according to the magnitude of their coefficient of variation $(\mathrm{CV})$, being considered low when $\mathrm{CV}$ is lower than $10 \%$, medium when $\mathrm{CV}$ is between 10 and $20 \%$, high when CV is between 20 and $30 \%$, and very high when $\mathrm{CV}$ is higher than $30 \%$. Thus, $\mathrm{BD}$ variability of the Oxisol was classified as medium, and that of the Ultisol was considered low (14.97 and 8.63\%, respectively).

\begin{tabular}{|c|c|c|c|c|c|c|c|c|c|}
\hline Attributes $^{2}$ & Mean & Median & Min & Max & SD & $\mathrm{CV}$ & Kurt & Asym & $\mathrm{Pw}<\mathrm{W}$ \\
\hline & \multicolumn{9}{|c|}{ Oxisol } \\
\hline $\mathrm{SD}\left(\right.$ dag $\left.\mathrm{kg}^{-1}\right)$ & 55.341 & 58.335 & 52.419 & 62.424 & 3.236 & 5.847 & 0.057 & 1.246 & $0.001 *$ \\
\hline SIL (dag $\left.\mathrm{kg}^{-1}\right)$ & 12.527 & 9.096 & 8.097 & 14.266 & 1.986 & 15.850 & 0.185 & -1.287 & $0.001 *$ \\
\hline $\mathrm{CL}\left(\right.$ dag $\left.\mathrm{kg}^{-1}\right)$ & 32.131 & 32.744 & 29.479 & 33.315 & 1.250 & 3.890 & -0.130 & -1.181 & $0.002 *$ \\
\hline $\mathrm{OM}\left(\mathrm{dag} \mathrm{kg}^{-1}\right)$ & 2.554 & 2.411 & 2.333 & 3.087 & 0.244 & 9.553 & 0.045 & 1.242 & $0.001 *$ \\
\hline $\mathrm{BD}\left(\mathrm{Mg} \mathrm{m}^{-3}\right)$ & 1.356 & 1.458 & 0.920 & 1.545 & 0.203 & 14.970 & -0.054 & -1.209 & $0.001 *$ \\
\hline$\theta F C\left(\mathrm{~m}^{3} \mathrm{~m}^{-3}\right)$ & 0.285 & 0.293 & 0.212 & 0.346 & 0.039 & 13.684 & -0.545 & -0.558 & $0.248^{\mathrm{ns}}$ \\
\hline \multirow[t]{2}{*}{$\theta \mathrm{PWP}\left(\mathrm{m}^{3} \mathrm{~m}^{-3}\right)$} & 0.160 & 0.168 & 0.132 & 0.172 & 0.014 & 8.750 & -0.170 & -1.275 & $0.000 *$ \\
\hline & \multicolumn{9}{|c|}{ Ultisol } \\
\hline $\mathrm{SD}\left(\right.$ dag $\left.\mathrm{kg}^{-1}\right)$ & 65.736 & 64.900 & 50.500 & 81.000 & 7.019 & 10.638 & 0.666 & 0.502 & $0.242^{\mathrm{ns}}$ \\
\hline SIL (dag kg-1) & 10.932 & 8.500 & 1.700 & 18.900 & 4.400 & 36.363 & -0.339 & -0.268 & $0.880^{\text {ns }}$ \\
\hline CL $\left(\right.$ dag $\left.k^{-1}\right)$ & 22.800 & 22.300 & 9.700 & 39.500 & 6.560 & 26.315 & 0.949 & 0.296 & $0.461^{\mathrm{ns}}$ \\
\hline $\mathrm{OM}\left(\operatorname{dag} \mathrm{kg}^{-1}\right)$ & 3.649 & 3.562 & 1.860 & 7.240 & 1.546 & 42.356 & -0.289 & 0.776 & $0.046^{*}$ \\
\hline $\mathrm{BD}\left(\mathrm{Mg} \mathrm{m}^{-3}\right)$ & 1.505 & 1.361 & 1.180 & 1.760 & 0.138 & 8.637 & 0.804 & -0.802 & $0.170^{\text {ns }}$ \\
\hline$\theta \mathrm{FC}\left(\mathrm{m}^{3} \mathrm{~m}^{-3}\right)$ & 0.210 & 0.209 & 0.160 & 0.260 & 0.043 & 20.476 & -2.214 & -0.265 & $0.002 *$ \\
\hline$\theta \mathrm{PWP}\left(\mathrm{m}^{3} \mathrm{~m}^{-3}\right)$ & 0.160 & 0.160 & 0.130 & 0.220 & 0.032 & 20.00 & 0.563 & 0.926 & $0.021 *$ \\
\hline
\end{tabular}

TABLE 3. Descriptive analysis of soil physical and chemical attributes of an Oxisol and Ultisol at a depth of $0.00-0.10 \mathrm{~m} .^{1}$

${ }^{1}$ Min: minimum, Max: Maximum, SD: standard deviation, CV: coefficient of variation (\%), Kurt: kurtosis, Asym: asymmetry, $\mathrm{Pw}<\mathrm{W}$ : $\mathrm{p}-\mathrm{value}$ of Shapiro-Wilk's test. ${ }^{2}$ CL: clay, ST: silt, SD: sand, BD: bulk density, OM: organic matter, $\Theta_{\mathrm{fc}}$ : soil water content in the field capacity, $\Theta_{\mathrm{pwp}}$ : soil water content in the permanent wilting point.

The texture of both soils was classified as medium, but the Oxisol presented a higher clay content (Table 1). The range of CL values varied from 29.479 to $33.315 \mathrm{dag} \mathrm{kg}^{-1}$ for the Oxisol and 9.700 to $39.500 \mathrm{dag} \mathrm{kg}^{-1}$ for the Ultisol, justifying the $\mathrm{CV}$ values classified as low and high, respectively. Despite the low variability of clay content in the Oxisol, these values are supposed to be preponderant over the variation of soil water content at specific potentials, especially those related to permanent wilting point.

Regarding OM content, a mean value of 3.649 dag $\mathrm{kg}^{-1}$ was observed for the Ultisol and 2.554 dag $\mathrm{kg}^{-1}$ for the Oxisol (Table 3). The maximum values indicated the existence of sites with a high decomposition capacity and stability of organic residues (3.087 and $7.240 \mathrm{dag} \mathrm{kg}^{-1}$ ). The highest $\mathrm{OM}$ variability was observed for the Ultisol $(42.35 \%)$.

Soil water content at equivalent tensions $\theta \mathrm{FC}$ and $\theta P W P$ presented mean values of 0.285 and $0.160 \mathrm{~m}^{3} \mathrm{~m}^{-3}$ for the Oxisol and 0.210 and $0.160 \mathrm{~m}^{3} \mathrm{~m}^{-3}$ for the Ultisol, respectively (Table 3). Despite the amplitude of $\mathrm{CL}$ contents, $\theta$ PWP values of both soils were very close. Klein et al. (2013) reported that $\theta$ PWP is also related to intraaggregate pores, with $\mathrm{BD}$ being the preponderant factor in the amount of cryptopores in soils. The structural units of aggregates are disrupted as BD increases, leading to an increase in textural pores, responsible for water retention at potentials lower than $-15000 \mathrm{hPa}$. In addition, clay increases the specific surface area of the soil matrix, and capillarity and adsorption phenomena determine the matric potential, responsible for soil water retention (Létourneau et al., 2015). Based on these observations, clay content and soil compaction (represented by BD) in these systems may have governed soil water retention conditions, especially in relation to potentials equivalent to $\theta \mathrm{PWP}$.

The Shapiro \& Wilk test confirmed the normal distribution for the attributes $\mathrm{CL}, \mathrm{SD}$, and $\theta \mathrm{FC}$ (Table 3). Although it was significant for the other attributes, indicating deviations from normality, the classifications were considered as distribution tending to normality since the mean values were close to the median. 
Tables 1 and 2 show the pedofunctions used to estimate soil water contents at specific potentials, theoretically $\theta \mathrm{FC}$ and $\theta \mathrm{PWP}$. Their respective coefficients of determination showed the quality of model adjustments, with $\mathrm{R}^{2}$ higher than 0.90 for most cases and all of them significant at $1 \%$ probability. A moderate to high correlation was verified between the observed and estimated $\theta F C$ data $(R>0.74)$, with a small tendency to overestimate values above $0.30 \mathrm{~m}^{3} \mathrm{~m}^{-3}$ and underestimate values below $0.20 \mathrm{~m}^{3} \mathrm{~m}^{-3}$ (Figure 2). Although the residuals of pedofunctions generated with soil data from Brazil (Arruda et al., 1987; van den Berg et al., 1987; Oliveira et al., 2002) were higher when compared to the other models, they presented a good performance even without taking into account attributes inherent to edaphology and soil compaction (i.e., OM and BD).

Contrary to what was observed in this study, Bonilla \& Cancino (2001) observed a low accuracy for Chilean soils. This limitation was overcome by working on a large database to allow a division of soils into more homogeneous classes. According to Reichert et al. (2009), point scattering is higher and water retention accuracy is lower when using pedofunctions generated from a database with characteristics that differ considerably from soils where the model is assessed. Pedofunctions will only efficiently express water retention of soils with genesis and mineralogy similar to that of the database that was generated (Mecke et al., 2002).
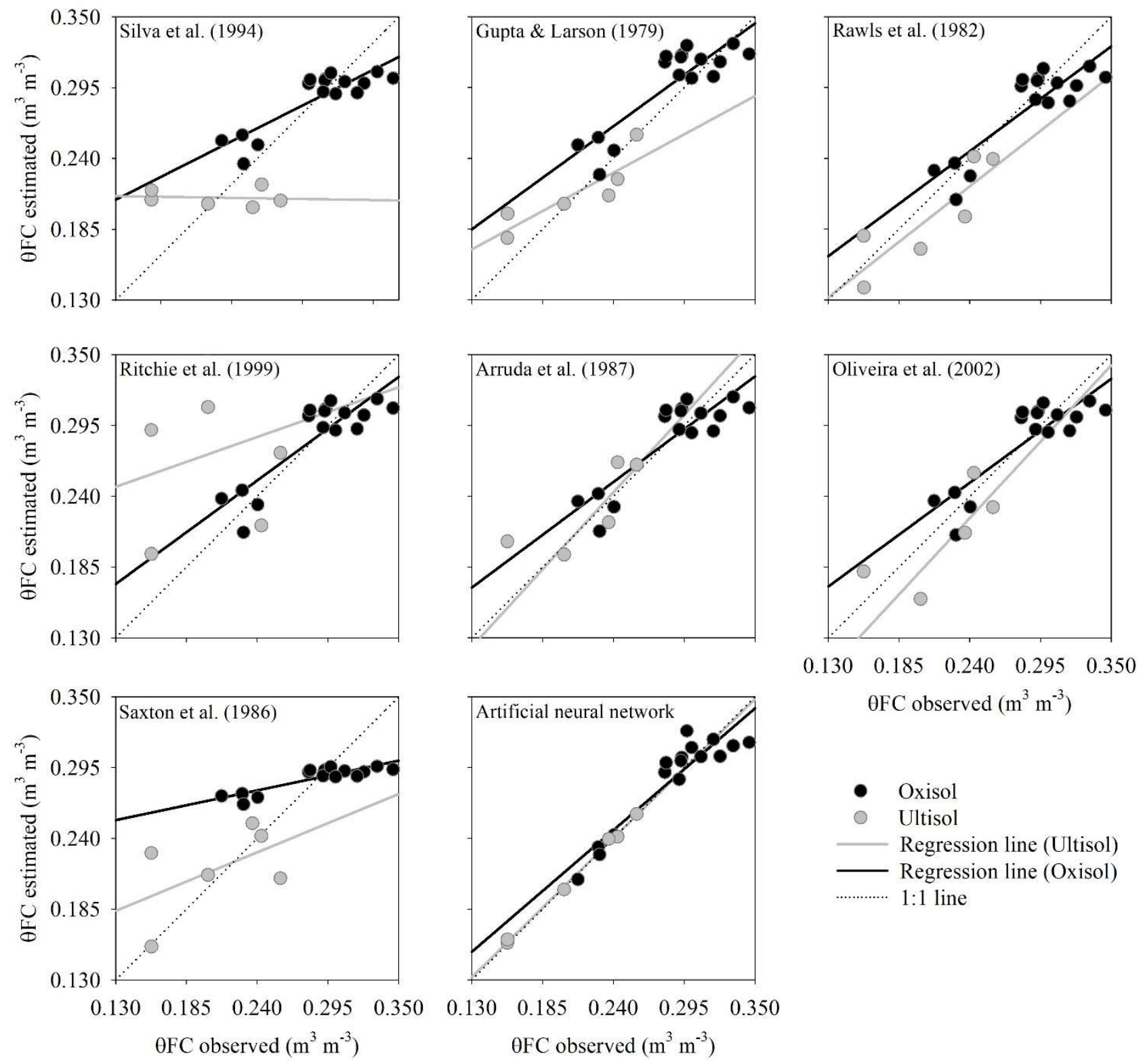

FIGURE 2. Linear regressions between observed and estimated $\theta \mathrm{FC}$ values obtained from the proposed models.

The estimates of $\theta \mathrm{PWP}$ presented lower point scattering and higher accuracy of models when compared to $\theta$ FC (Figure 3). All tested functions were close to the $1: 1$ line on a $45^{\circ}$ slope, except for the functions of Ritchie et al. (1999) and Silva et al. (1994). This behavior reflected a high correlation of estimates with the observed data due to an $\mathrm{R}^{2}$ higher than 0.90. In addition, the results showed that changes imposed on the Oxisol by agriculture led to an increase in water volume retained at potentials lower than $-15000 \mathrm{hPa}$, in which $\theta \mathrm{PWP}$ values were higher than 0.16 $\mathrm{m}^{3} \mathrm{~m}^{-3}$ in most cases, even in integrated production systems. The estimates of $\theta \mathrm{PWP}$ allowed a more detailed 
observation of the Oxisol database, in which OM and BD contents were not significant in the pedofunctions of Gupta \& Larson (1979), van den Berg et al. (1987), and Oliveira et al. (2002) (Table 2). On the other hand, OM and BD contents were significant in the adjustment of $\theta \mathrm{PWP}$ functions for the Ultisol. According to Rawls et al. (2003), the use of contents of soil organic carbon and their particle size distribution as predictors leads to a small improvement in water content predictions related to the matric potential of $-15000 \mathrm{hPa}$ when compared to functions that use only particle size distribution as predictors.

Bonetti et al. (2017) studied the water retention of an Oxisol and Ultisol under integrated crop-livestock systems (ICL) and verified that changes imposed by the management system on soil porosity modified $\theta \mathrm{FC}$ to a higher degree when compared to $\theta$ PWP. The adequate animal stocking rate and dwell time of the forage crop in ICL can favor the reorganization of porous space by the root system development. This strategy contributes to increasing the water content available to plants, with direct changes in microporosity (Bonetti et al., 2017). In this sense, the management system adopted for the Oxisol (ICL with an intensive crop rotation and high animal stocking rate) may not have been adequate to the maintenance of a pore structure with a diameter lower than $0.2 \mu \mathrm{m}$, which favored micropore disruption, directly reinforcing the effect of clay contents under soil compaction conditions. In this case, the function adjustment procedure itself is responsible for maintaining or excluding a certain attribute, aiming at the adequacy of adjustment coefficients, as well as the errors between the generated output patterns to reach the desired minimum value, i.e., close to zero.
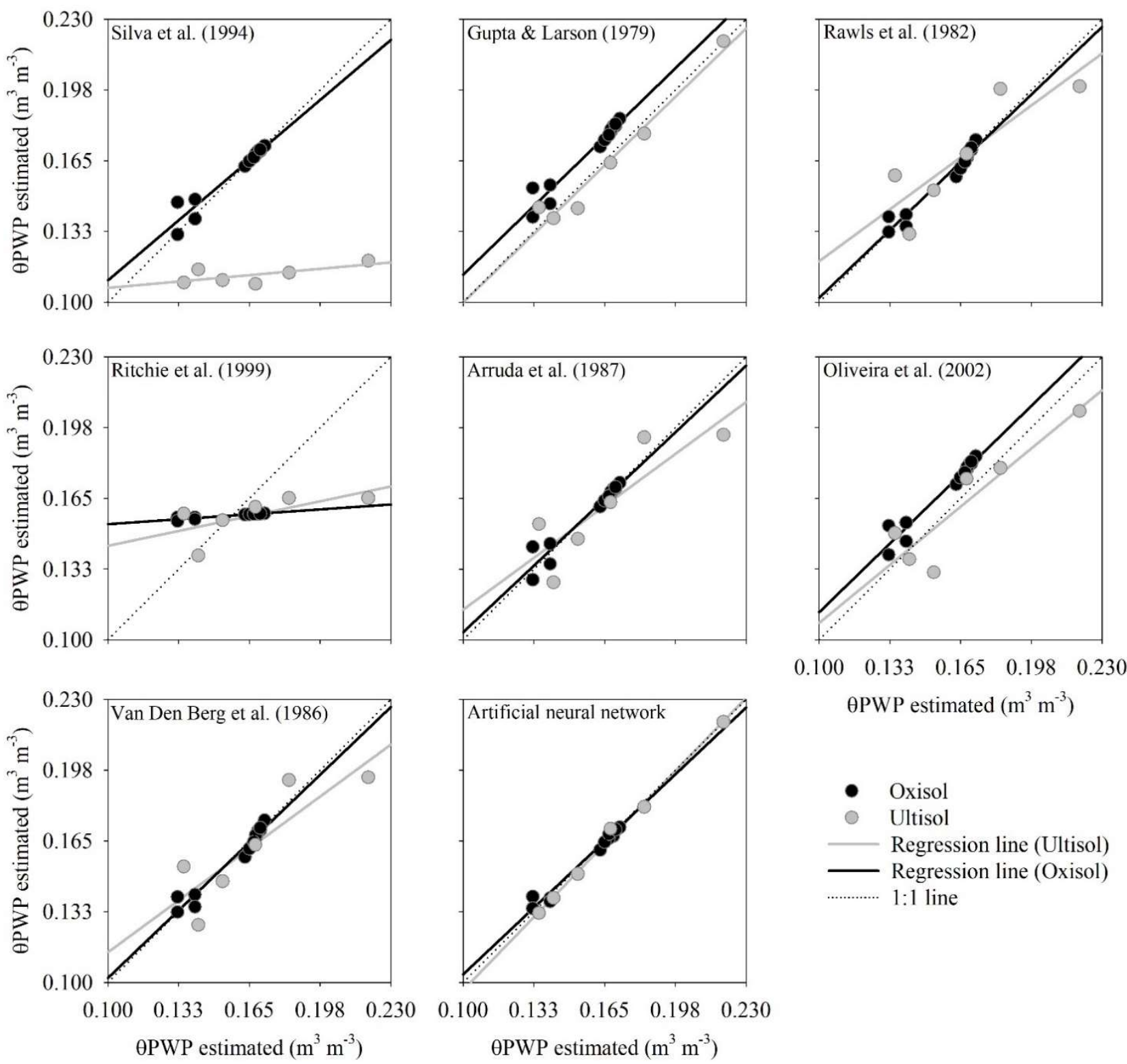

$\theta$ PWP estimated $\left(\mathrm{m}^{3} \mathrm{~m}^{-3}\right)$

- Oxisol

- Ultisol

Regression line (Ultisol)

- Regression line (Oxisol)

…….... $1: 1$ line

FIGURE 3. Linear regressions between observed and estimated $\theta$ PWP values obtained from the proposed models. 
As in $\mathrm{R}^{2}$, ANN showed higher efficiency in the estimation of $\theta F C$ and $\theta$ PWP. ANN, Arruda et al. (1987), and van den Berg et al. (1987) were the best classified for the MSE, RMSE, and MAPE values of the pedofunctions that estimated $\theta \mathrm{FC}$ (Table 4). On the other hand, ANN, Rawls et al. (1982), and van den Berg et al. (1987), in this order, were the best for those that estimated $\theta \mathrm{PWP}$. MSE was a sensitive evaluator to errors of pedofunctions because it raised the individual differences between the observed and estimated squared values. This evaluator is always positive and, when zero, indicates the perfect model simulation. In addition to MSE, RMSE also expresses the accuracy of results, with error values under the same dimensions of the analyzed variable. MAPE is a less robust evaluator and showed the error representativeness in relation to the total of the measured observations. In this case, ANNs were classified first in the pedofunctions rank, with lower MSE, RMSE, and MAPE in both $\theta \mathrm{FC}$ and $\theta \mathrm{PWP}$ estimates.

TABLE 4. Mean square error (MSE), root mean square error (RMSE), and mean absolute percentage error (MAPE) calculated from the proposed $\theta \mathrm{FC}$ and $\theta \mathrm{PWP}$ pedofunctions.

\begin{tabular}{|c|c|c|c|c|c|c|c|c|}
\hline \multirow{2}{*}{ Fonte } & \multicolumn{4}{|c|}{$\theta \mathrm{FC}$} & \multicolumn{4}{|c|}{$\theta \mathrm{PWP}$} \\
\hline & MSE & RMSE & MAPE & $\operatorname{Rank}^{1}$ & MSE & RMSE & MAPE & $\operatorname{Rank}^{1}$ \\
\hline & \multicolumn{8}{|c|}{ Oxisol } \\
\hline Silva et al. (1994) & 0.0004 & 0.0220 & 0.0118 & $6^{\text {th }}$ & $1.54 \times 10^{-5}$ & 0.0039 & 0.0075 & $5^{\text {th }}$ \\
\hline Gupta \& Larson (1979) & 0.0005 & 0.0228 & 0.0485 & $7^{\text {th }}$ & 0.0001 & 0.0114 & 0.0694 & $6^{\text {th }}$ \\
\hline Rawls et al. (1982) & 0.0004 & 0.0202 & 0.0184 & $5^{\text {th }}$ & $9.08 \times 10^{-6}$ & 0.0030 & 0.0029 & $2^{\text {nd }}$ \\
\hline Saxton et al. (1986) & 0.0009 & 0.0304 & 0.0189 & $8^{\text {th }}$ & - & - & - & - \\
\hline Ritchie et al. (1999) & 0.0826 & 0.2875 & 0.0046 & $9^{\text {th }}$ & 0.0001 & 0.0135 & 0.0103 & $8^{\text {th }}$ \\
\hline Arruda et al. (1987) & 0.0003 & 0.0192 & 0.0021 & $2^{\text {nd }}$ & $1.17 \times 10^{-5}$ & 0.0034 & 0.0004 & $4^{\text {th }}$ \\
\hline van den Berg et al. (1987) & 0.0003 & 0.0193 & 0.0119 & $3^{\text {rd }}$ & $9.08 \times 10^{-6}$ & 0.0030 & 0.0029 & $3^{\text {rd }}$ \\
\hline Oliveira et al. (2002) & 0.0003 & 0.0194 & 0.0012 & $4^{\text {th }}$ & 0.0001 & 0.0114 & 0.0694 & $7^{\text {th }}$ \\
\hline \multirow[t]{2}{*}{ Artificial neural network } & 0.0002 & 0.0142 & 0.0018 & $1^{\text {st }}$ & $5.22 \times 10^{-6}$ & 0.0022 & 0.0019 & $1^{\text {st }}$ \\
\hline & \multicolumn{8}{|c|}{ Ultisol } \\
\hline Silva et al. (1994) & 0.0016 & 0.0411 & 0.0424 & $7^{\text {th }}$ & 0.0036 & 0.0601 & 0.3087 & $8^{\text {th }}$ \\
\hline Gupta \& Larson (1979) & 0.0004 & 0.0222 & 0.0338 & $2^{\text {nd }}$ & $3.73 \times 10^{-5}$ & 0.0061 & 0.0121 & $2^{\text {nd }}$ \\
\hline Rawls et al. (1982) & 0.0006 & 0.0256 & 0.0654 & $4^{\text {th }}$ & 0.0002 & 0.0146 & 0.0137 & $3^{\text {rd }}$ \\
\hline Saxton et al. (1986) & 0.0012 & 0.0359 & 0.0587 & $6^{\text {th }}$ & - & - & - & - \\
\hline Ritchie et al. (1999) & 0.0080 & 0.0895 & 0.3519 & $8^{\text {th }}$ & 0.0006 & 0.0254 & 0.0371 & $6^{\text {th }}$ \\
\hline Arruda et al. (1987) & 0.0005 & 0.0229 & 0.0588 & $3^{\text {rd }}$ & 0.0002 & 0.0151 & 0.0170 & $4^{\text {th }}$ \\
\hline van den Berg et al. (1987) & - & - & - & - & 0.0002 & 0.0151 & 0.0170 & $5^{\text {th }}$ \\
\hline Oliveira et al. (2002) & 0.0012 & 0.0357 & 0.0989 & $5^{\text {th }}$ & 0.0008 & 0.0291 & 0.0915 & $7^{\text {th }}$ \\
\hline Artificial neural network & $4.94 \times 10^{-6}$ & 0.0022 & 0.0043 & $1^{\text {st }}$ & $6.56 \times 10^{-6}$ & 0.0025 & 0.0096 & $1^{\text {st }}$ \\
\hline
\end{tabular}

${ }^{1}$ Rank: classification based in lower MSE, RMSE and MAPE.

The estimates generated by these two adjustment categories could be considered as satisfactory and valid, but the use of multiple linear regression models to predict $\theta \mathrm{FC}$ values below $0.20 \mathrm{~m}^{3} \mathrm{~m}^{-3}$ may present a slight tendency to overestimate it, which was not observed by the neural network. The pedofunctions applied to LLWR showed that the available soil water content (AW), represented by the difference between $\theta \mathrm{FC}$ and $\theta \mathrm{PWP}$, was positively influenced by an increase in BD between 0.69 and $1.06 \mathrm{Mg}$ $\mathrm{m}^{-3}$ in all cases (Figure 4C, D). This behavior confirms the positive relationship between soil compaction and the available water range (without considering restrictions imposed by $\theta \mathrm{PR}$ ), in which the water content retained at potentials of -100 and $-15000 \mathrm{hPa}$ is higher. The models proposed by Silva et al. (1994) and Ritchie et al. (1999) stood out from the other pedofunctions in both soils, indicating an excess LLWR of $0.02 \mathrm{~m}^{3} \mathrm{~m}^{-3}$ in the Oxisol (Figure 4A) and a deficit of $0.04 \mathrm{~m}^{3} \mathrm{~m}^{-3}$ in the Ultisol (Figure 4B) based on the estimates carried out by ANN, which had the best performance in both soils. 


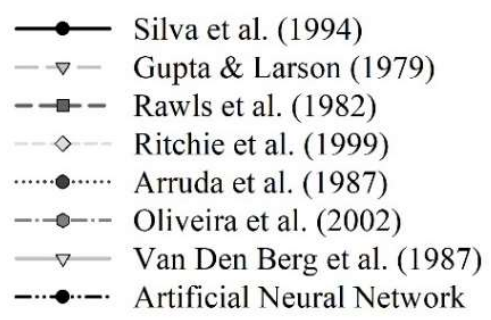

(A)

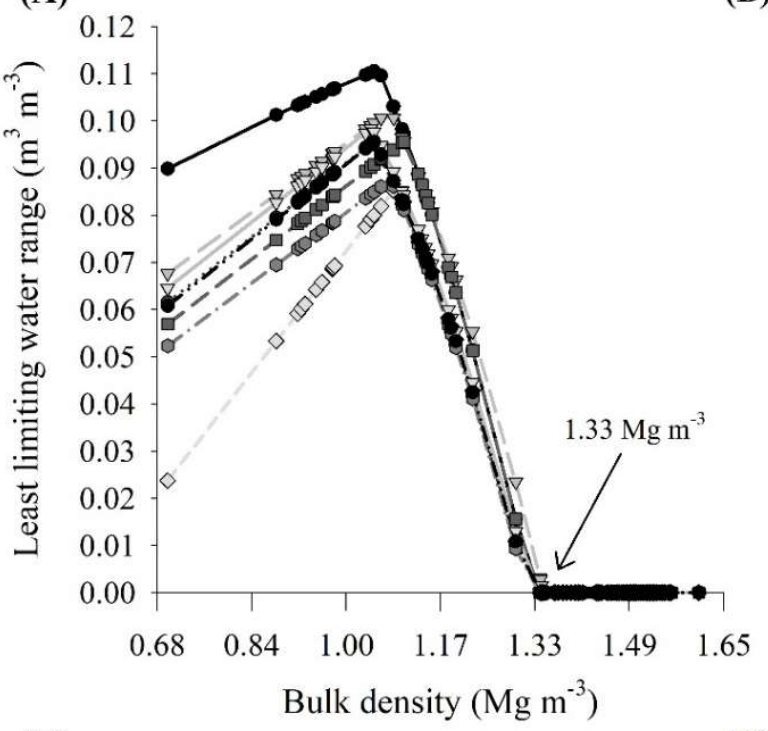

(C)

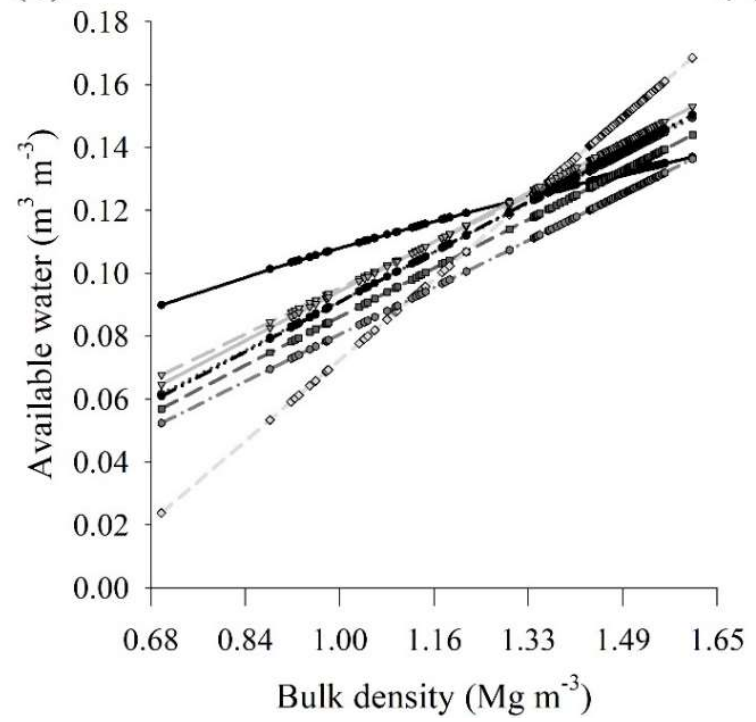

(B)

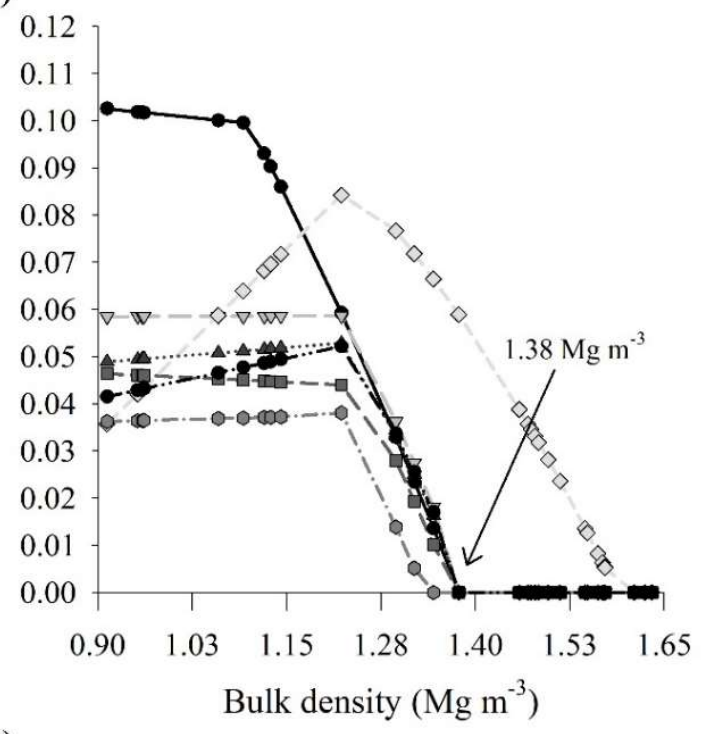

(D)

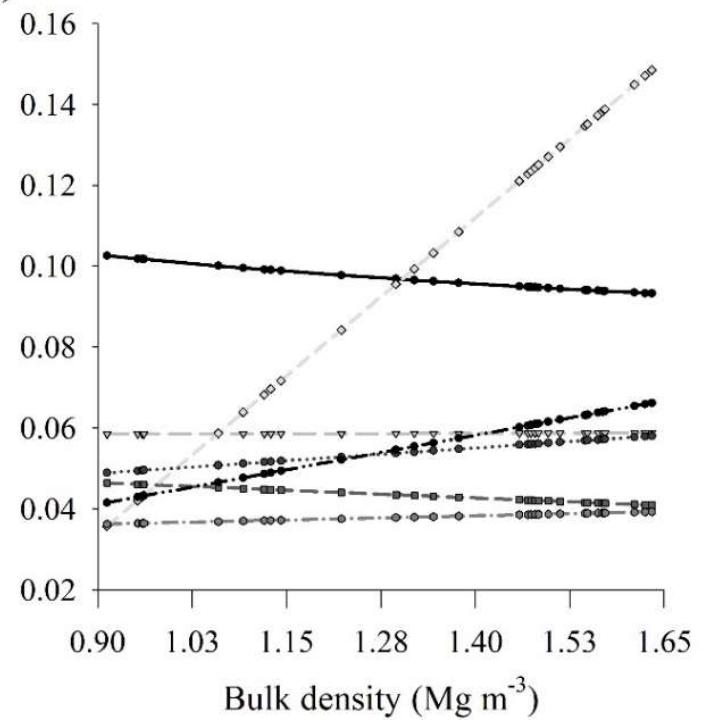

FIGURE 4. Variation of LLWR in the Oxisol (A) and Ultisol (B) and available water content in the Oxisol (C) and Ultisol (D) using the tested pedofunctions.

Regarding the critical BD, in which LLWR is zero, all the proposed models for Oxisol showed LLWR zero for a BD of $1.33 \mathrm{Mg} \mathrm{m}^{-3}$, while most of the models for the Ultisol presented LLWR zero for a BD of $1.38 \mathrm{Mg} \mathrm{m}^{-3}$ (Figure 4A, B). In this case, the models of Oliveira et al. (2002) and Ritchie et al. (1999) underestimated and overestimated the critical BD in the Ultisol, respectively. For LLWR construction in the Ultisol using the pedofunctions proposed by Oliveira et al. (2002), the critical $\mathrm{BD}$ would be $1.35 \mathrm{Mg} \mathrm{m}^{-3}$, while using the pedofunctions proposed by Ritchie et al. (1999), the critical BD would be $1.61 \mathrm{Mg} \mathrm{m}^{-3}$ (Figure 4B). Considering that LLWR accesses soil physical quality through $\mathrm{BD}$, the main objective of its determination is to clarify the critical BD so that preventive actions are taken in agricultural systems. In the evaluated systems, the $\theta \mathrm{PR}$ curve was the preponderant factor in the establishment of the critical BD.

Regardless of the pedofunctions used for LLWR construction in the Oxisol, it was not restricted by the airfilled capacity curve $(\theta \mathrm{AFC}$ ) (Figure 5). The $\theta \mathrm{AFC}$ was above $\theta \mathrm{FC}$ in all cases, not being a preponderant factor even at high BD levels. According to Gubiani et al. (2013), there are practically no criticisms reported in the Brazilian literature for the upper LLWR limits. Most crops are grown on soils with optimum drainage, where the period of water excess, i.e., soil aeration deficiency is much lower when compared to periods of water deficit. Under these soil conditions, studies have indicated a higher relationship of plant development with PR (Freddi et al., 2009; Kaiser et al., 2009), being more frequent than with $\theta \mathrm{AFC}$. 


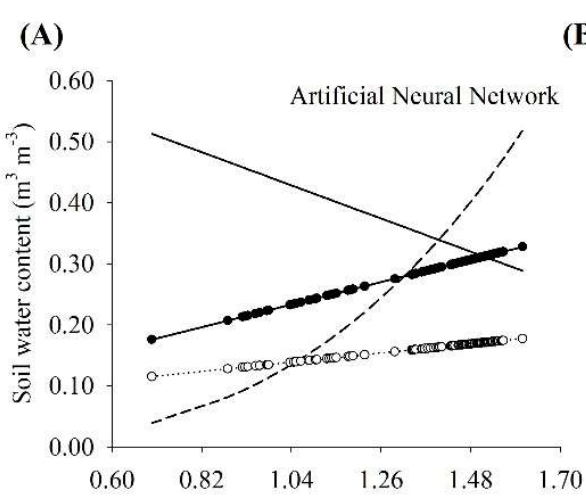

(D)

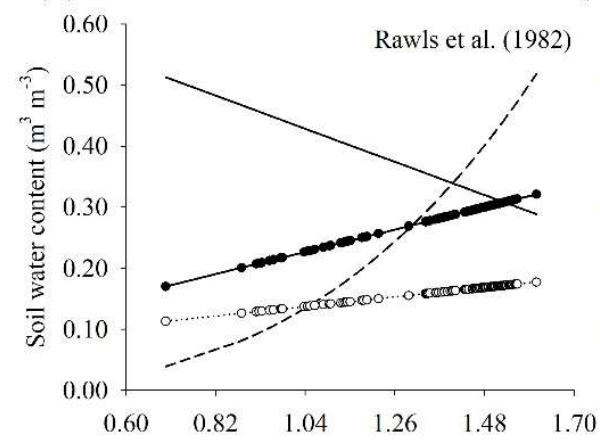

(G)

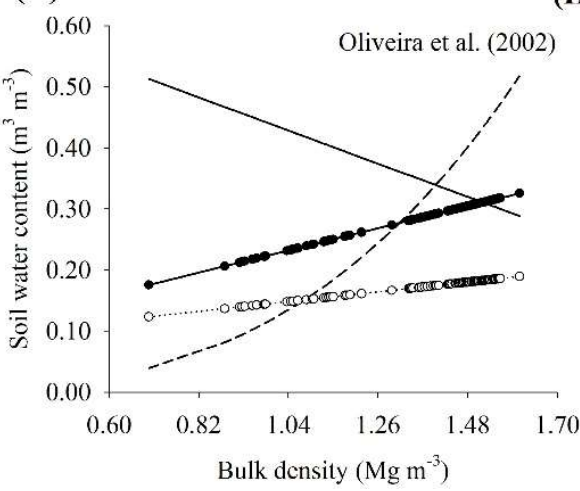

(H)

E)
(B)
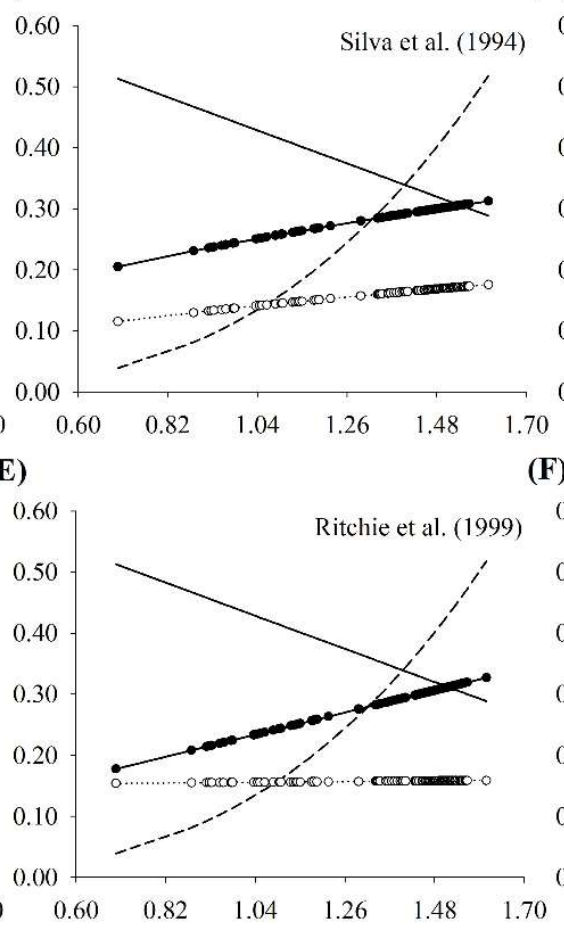

(F)

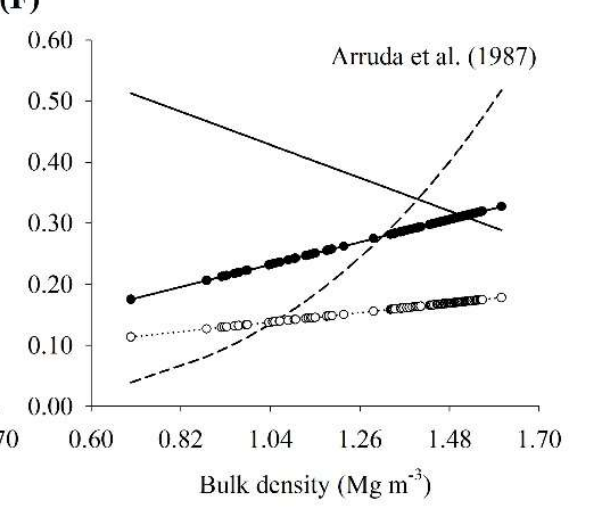

(C)

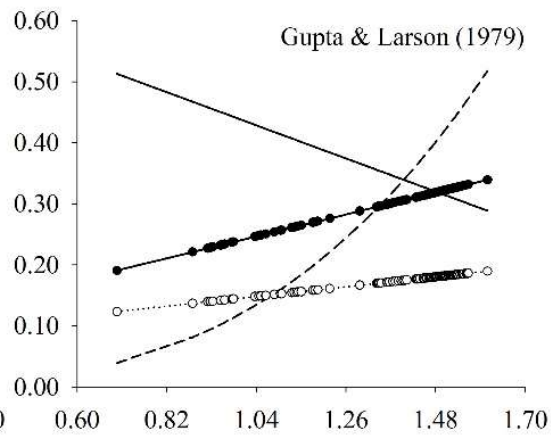

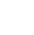

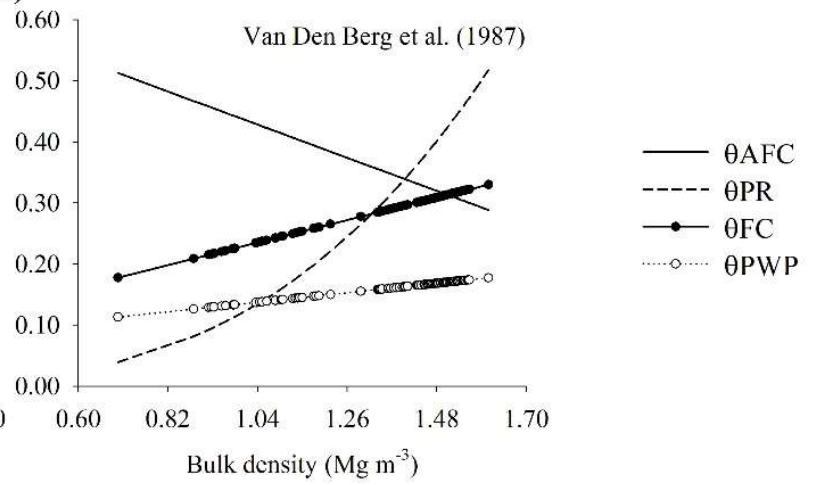

FIGURE 5. LLWR construction of the Oxisol as a function of soil bulk density using the proposed pedofunctions to estimate $\theta \mathrm{FC}$ and $\theta \mathrm{PWP}$.

When the proposed pedofunctions are used to construct the LLWR concept, it is evident that the main changes occur on the available soil water content (AW). In the Oxisol, LLWRs estimated by ANN, Gupta \& Larson (1979), Rawls et al. (1982), Ritchie et al. (1999), Arruda et al. (1987), Oliveira et al. (2002), and van den Berg et al. 

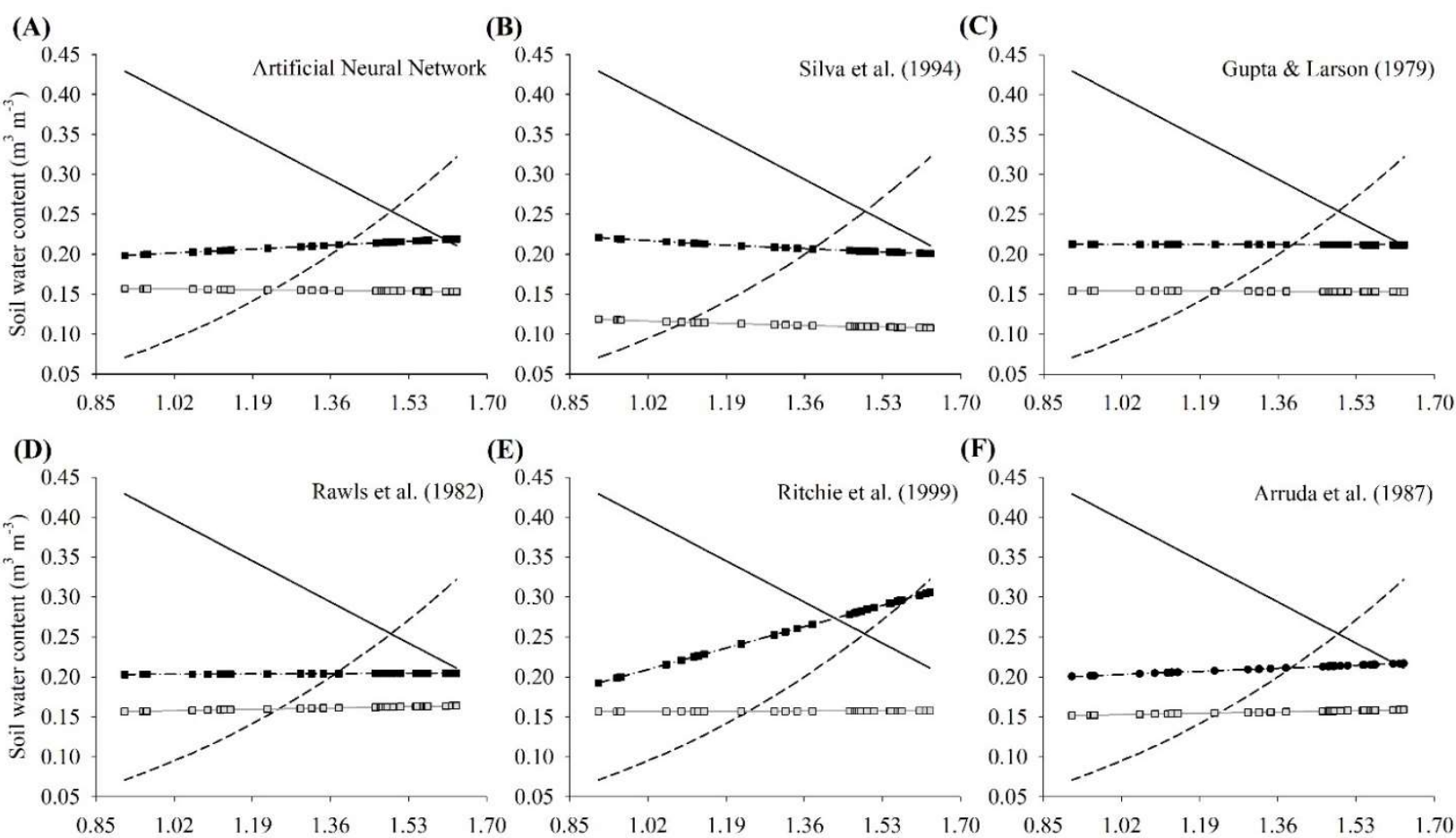

(E)

(F)
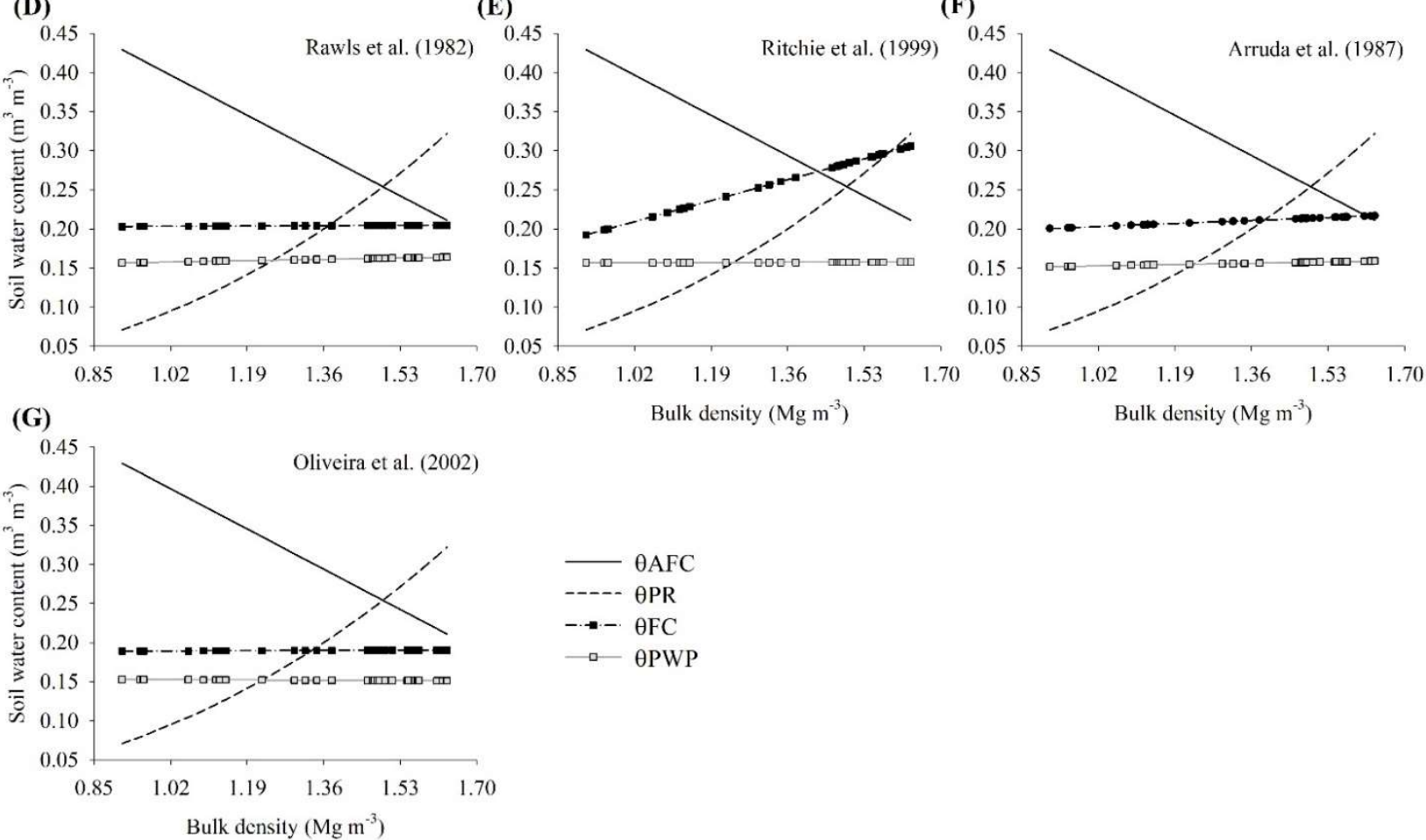

FIGURE 6. LLWR construction of the Ultisol as a function of soil bulk density using the proposed pedofunctions to estimate $\theta \mathrm{FC}$ and $\theta \mathrm{PWP}$

Considering the results obtained for the Ultisol, it was evident that AW was overestimated under all BD conditions when the pedofunctions proposed by Silva et al. (1994) were used (Figure 6B). The model proposed by Ritchie et al. (1999), as observed for the Oxisol, underestimated $\mathrm{AW}$ at low $\mathrm{BD}$ levels and overestimated AW at high BD levels, which would restrict its use for this type of soil (Figure 6E).

The results obtained in this study provided important information for the management of compacted and/or irrigated areas, demonstrating the use of the main models to estimate $\theta \mathrm{FC}$ and $\theta \mathrm{PWP}$, the result on LLWR determination, and available water of two soils frequently found in Brazil. In addition, further studies using a larger database are needed, allowing the establishment of an artificial neural network that could be validated for Brazilian soils or tropical regions.

\section{CONCLUSIONS}

Among the evaluated pedofunctions, multilayer perceptron artificial neural networks are more efficient to estimate water contents in the field capacity and permanent wilting point.
Pedofunctions that use contents of sand, clay, organic matter, and soil bulk density are more efficient in estimating water contents in the field capacity and permanent wilting point.

Multiple linear regression techniques are inferior regarding statistics that measure the accuracy of models and tend to overestimate water content values in the field capacity.

Pedofunctions differ in the establishment of the critical bulk density when they are used to calculate the least limiting water range, exposing the limitations of the models.

\section{ACKNOWLEDGMENTS}

To the Coordination for the Improvement of Higher Education Personnel (CAPES) for granting the scholarship to the first author. To Embrapa Agrosilvopastoral and Certeza Farm for providing one of the areas for study.

\section{REFERENCES}

Arruda FB, Zullo Junior J, Oliveira JD (1987) Parâmetros de solo para o cálculo da água disponível com base na textura do solo. Revista Brasileira de Ciência do Solo $11: 11-15$ 
Barros AHC, Jong Van Lier QD, Maia ADHN, Scarpare FV (2013) Pedotransfer functions to estimate water retention parameters of soils in northeastern Brazil. Revista Brasileira de Ciência do Solo 37(2):379-391. DOI: http://dx.doi.org/10.1590/S0100-06832013000200009

Betioli Junior E, Moreira WH, Tormena CA, Bernabe Ferreira CJ, Silva AP, Giarola NFB (2012) Intervalo hídrico ótimo e grau de compactação de um Latossolo Vermelho após 30 anos sob plantio direto. Revista Brasileira de Ciência do Solo 36(3):971-982. DOI: http://dx.doi.org/10.1590/S0100-06832012000300027

Bonetti JA, Anghinoni I, de Moraes MT, Fink JR (2017) Resilience of soils with different texture, mineralogy and organic matter under long-term conservation systems. Soil and Tillage Research 174:104-112. DOI:

https://doi.org/10.1016/j.still.2017.06.008

Bonilla M, Cancino V (2001) Estimación del contenido de humedad del suelo mediante el empleo de funciones de pedotransferência. Agricultura Técnica 61(3):326-338. DOI: http://dx.doi.org/10.4067/S0365-

28072001000300008

Busscher WJ (1990) Adjustment of flat-tipped penetrometer resistance data to a common water content. Transactions of the ASAE 33(2):519-0524.

Cecagno D, de Andrade SEVG, Anghinoni I, Kunrath TR, Martins AP, Reichert JM, Gubiani PI, Balerini F, Fink JR, de Faccio Carvalho PC (2016) Least limiting water range and soybean yield in a long-term, no-till, integrated croplivestock system under different grazing intensities. Soil and Tillage Research 156:54-62. DOI:

https://doi.org/10.1016/j.still.2015.10.005

Ebrahimi M, Sarikhani MR, Sinegani AAS, Ahmadi A, Keesstra S (2019) Estimating the soil respiration under different land uses using artificial neural network and linear regression models. Catena 174(3):371-382. DOI: https://doi.org/10.1016/j.catena.2018.11.035

Embrapa Solos - Empresa Brasileira de Pesquisa Agropecuária (2011) Manual de métodos de análise de solo. Empresa Brasileira de Pesquisa Agropecuária Solos, 212p.

Embrapa Solos - Empresa Brasileira de Pesquisa Agropecuária (2013) Sistema Brasileiro de Classificação de solos. Empresa Brasileira de Pesquisa Agropecuária Solos, 353p.

Freddi OS, Centurion JF, Duarte AP, Peres FSC (2009) Compactação do solo e produção de cultivares de milho em Latossolo Vermelho. II - Intervalo hídrico ótimo e sistema radicular. Revista Brasileira de Ciência do Solo 33(4):805-818.

Gubiani PI, Reichert JM, Reinert DJ (2013) Indicadores hídrico-mecânicos de compactação do solo e crescimento de plantas. Revista Brasileira de Ciência do Solo 37(1):110. DOI: https://doi.org/10.1590/S010006832013000100001

Guimarães RM, Tormena CA, Blainski É, Fidalski, J (2013) Intervalo hídrico ótimo para avaliação da degradação física do solo. Revista Brasileira de Ciência do Solo 37(6):1512-1521. DOI: http://dx.doi.org/10.1590/S0100-06832013000600008
Gupta S, Larson WE (1979) Estimating soil water retention characteristics from particle size distribution, organic matter percent, and bulk density. Water resources research 15(6):1633-1635.

Jana RB, Mohanty BP (2012) A comparative study of multiple approaches to soil hydraulic parameter scaling applied at the hill-slope scale. Water Resources Research 48(2):1-16. DOI:

http://dx.doi.org/10.1029/2010WR010185

Jana RB, Mohanty BP, Sheng Z (2012) Upscaling soil hydraulic parameters in the Picacho Mountain region using Bayesian neural networks. Transactions of the ASABE 55(2):463-473. DOI:

http://dx.doi.org/10.13031/2013.41396

Jong Van Lier QD, Gubiani PI (2015) Beyond the "least limiting water range": Rethinking soil physics research in Brazil. Revista Brasileira de Ciência do Solo 39(4):925939. DOI:

http://dx.doi.org/10.1590/01000683rbcs20140596

Klein VA, Graebin GJ, Bortolanza DR, Daubermann AG (2016) Spatial variability of the least limiting water range of soils under a no-tillage system. Pesquisa Agropecuária Brasileira 51(11):1890-1898. DOI: http://dx.doi.org/10.1590/s0100-204x2016001100011

Klein VA, Navarini LL, Klein C, da Costa LO, Barbosa EA, Steffler VA (2013) Propriedades físicas do solo e rendimento de grãos de trigo em função de manejo do solo e uso de bioestimulantes. Pesquisa Agropecuária Gaúcha 19(1):24-32.

Leal AJF, Pereira Miguel E, Rojo Baio FH, Neves DC, Leal UAS (2015) Redes neurais artificiais na predição da produtividade de milho e definição de sítios de manejo diferenciado por meio de atributos do solo. Bragantia 74(4):436-444. DOI: http://dx.doi.org/10.1590/16784499.0140

Letey J (1985) Relationship between soil physical properties and crop productions. In: Stewart BA (eds). Advances in Soil Science. Springer, p277-294.

Létourneau G, Caron J, Anderson L, Cormier J (2015) Matric potential-based irrigation management of fieldgrown strawberry: Effects on yield and water use efficiency. Agricultural Water Management 161:102-113. DOI: https://doi.org/10.1016/j.agwat.2015.07.005

Mecke M, Westman CJ, Ilvesniemi H (2002) Water retention capacity in coarse podzol profiles predicted from measured soil properties. Soil Science Society of America Journal 66(1):1-11. DOI: http://dx.doi.org/10.2136/sssaj2002.1000

Medeiros JC, Cooper M, Dalla Rosa J, Grimaldi M, Coquet Y (2014) Assessment of pedotransfer functions for estimating soil water retention curves for the amazon region. Revista Brasileira de Ciência do Solo 38(3):730743. DOI: http://dx.doi.org/10.1590/S010006832014000300005

Medrado E, Lima JE (2014) Development of pedotransfer functions for estimating water retention curve for tropical soils of the Brazilian savanna. Geoderma Regional 1:5966. DOI: https://doi.org/10.1016/j.geodrs.2014.08.003 
Nguyen PM, Haghverdi A, De Pue J, Botula YD, Le KV, Waegeman W, Cornelis WM (2017) Comparison of statistical regression and data-mining techniques in estimating soil water retention of tropical delta soils. Biosystems Engineering 153:12-27. DOI: https://doi.org/10.1016/j.biosystemseng.2016.10.013

Oliveira LB, Ribeiro MR, Jacomine PKT, Rodrigues JJV, Marques FA (2002) Funções de pedotransferência para predição da umidade retida a potenciais específicos em solos do estado de Pernambuco. Revista Brasileira de Ciência do Solo 26(2):315-322. DOI:

http://dx.doi.org/10.1590/S0100-06832002000200004

R Development Core Team (2015) A Language and Environment for Statistical Computing. R Foundation for Statistical Computing. Vienna, Austria. Available from http://www.R-project.org/.

Rawls WJ, Brakensiek DL, Saxtonn KE (1982) Estimation of soil water properties. Transactions of the ASAE 25(5):1316-1320.

Rawls WJ, Pachepsky YA, Ritchie JC, Sobecki TM, Bloodworth H (2003) Effect of soil organic carbon on soil water retention. Geoderma 116(1-2):61-76.

Reichert JM, Albuquerque JA, Kaiser DR, Reinert DJ, Urach FL, Carlesso R (2009) Estimation of water retention and availability in soils of Rio Grande do Sul. Revista Brasileira de Ciência do Solo 33(6):1547-1560. DOI: http://dx.doi.org/10.1590/S0100-06832009000600004
Ritchie JT, Gerakis A, Suleiman A (1999) Simple model to estimate field-measured soil water limits. Transactions of the ASAE 42(6):1609-1614. DOI: http://dx.doi.org/10.13031/2013.13326

Saxton KE, Rawls W, Romberger JS, Papendick RI (1986) Estimating generalized soil-water characteristics from texture. Soil Science Society of America Journal 50(4):1031-1036.

Silva AP, Kay BD, Perfect E (1994) Characterization of the Least Limiting Water Range of Soils. Soil Science Society of America Journal 58(6):1775-1781. DOI: http://dx.doi.org/10.2136/sssaj1994.03615995005800060028x

Soil Survey Staff (2014) Keys to soil taxonomy. Washington DC, United States Department of Agriculture, $12^{\text {th }}$ ed. 360 p.

Taylor HM, Roberson GM, Parker Jr JJ (1966) Soil strength-root penetration relations for medium-to coarsetextured soil materials. Soil Science 102(1):18-22.

Tormena CA, Silva AP, Libardi PL (1998) Caracterização do intervalo hídrico ótimo de um latossolo roxo sob plantio direto. Revista Brasileira de Ciência do Solo 22(4):573-581. DOI: http://dx.doi.org/10.1590/S010006831998000400002

van den Berg M, Klamt E, van Reeuwijk LP, Sombroek WG (1997) Pedotransfer functions for the estimation of moisture retention characteristics of Ferralsols and related soils. Geoderma 78(3-4):161-180. DOI: https://doi.org/10.1016/S0016-7061(97)00045-1 